\title{
Randomized control trial evidence for the benefits of massage and relaxation therapy on sleep in cancer survivors-a systematic review
}

\author{
Stephen Rajan Samuel ${ }^{1} \cdot$ Rachita Gururaj $^{1} \cdot$ K. Vijaya Kumar ${ }^{1}$ (D) Prina Vira ${ }^{1}$ • P. U. Prakash Saxena ${ }^{2}$. \\ Justin William Leslie Keogh 1,3,4,5
}

Received: 24 July 2020 / Accepted: 17 November 2020 / Published online: 2 December 2020

(C) The Author(s) 2020

\begin{abstract}
Purpose Cancer survivors may experience sleep disturbances during and after their cancer treatments. While pharmacological approaches are commonly used to address sleep disturbances, they may have a number of adverse effects. This review studied the effect of two non-pharmacological interventions (massage and relaxation therapy) on sleep disturbances in cancer survivors.

Methods A search for randomised controlled trials (RCTs) was conducted on PubMed, Scopus, Web of Science, PEDro, and CINAHL using relevant keywords.

Results The search yielded 371 articles, with 4 RCTs studying massage therapy and 3 RCTs studying relaxation therapy included for qualitative analysis. Massage therapy studies showed statistically significant improvement in self-reported sleep questionnaires and objectively recorded long sleep episodes, as assessed via an accelerometer. No significant improvements in sleep outcomes were observed in the relaxation therapy studies, although there were trends for improved self-reported sleep quality. Conclusion While massage therapy provided by massage therapists may have some potential for improving sleep outcomes for cancer survivors, there is no such current evidence regarding relaxation therapy.

Implications for Cancer Survivors Cancer survivors who experience sleep disturbances may benefit from regular sessions with a massage therapist. However, future studies should examine the long-term feasibility of massage therapist-delivered services, particularly for cancer survivors with limited finances, and determine if benefits can be obtained if massage is provided by noncertified individuals. Relaxation therapy appears to be safe for cancer survivors, but future RCTs involving larger sample sizes need to be conducted to better determine its feasibility and efficacy.
\end{abstract}

Keywords Massage $\cdot$ Relaxation therapy $\cdot$ Sleep wake disorders $\cdot$ Carcinoma

K. Vijaya Kumar

vijay.kk@manipal.edu

1 Department of Physiotherapy, Kasturba Medical College, Mangalore, Manipal Academy of Higher Education, Manipal, India

2 Department of Radiation Oncology at Kasturba Medical College, Mangalore, Manipal Academy of Higher Education, Manipal, India

3 Faculty of Health Sciences and Medicine, Bond University, Gold Coast, Australia

4 Human Potential Centre, AUT University, Auckland, New Zealand

5 Cluster for Health Improvement, Faculty of Science, Health, Education and Engineering, University of the Sunshine Coast, Sunshine Coast, Australia

\author{
Abbreviations \\ CBT Cognitive behavioral therapy \\ CSHQ Children sleep habits questionnaire \\ NRSSS Numerical Rating Scale of Satisfaction of Sleep \\ PROMIS Patient-Reported Outcomes Measurement \\ Information System for Sleep - Short Form \\ PSQI Pittsburgh Sleep Quality Index \\ RCSQ Richards-Campbell Sleep Questionnaire \\ RCT Randomized controlled trial
}

\section{Introduction}

Sleep disturbance is one of the most distressing symptoms experienced by cancer survivors not only at the time of diagnosis and treatment but also affecting $51 \%$ of cancer survivors beyond 5 
years post-treatment $[1,2]$. As such, the prevalence of sleep disturbances in cancer survivors is nearly twice that found in the general population [3]. Long-term sleep disturbances can lead to distress, increased morbidity, reduced productivity, and poor quality of life [1, 4], with these disturbances in cancer populations having been attributed to a variety of factors. These may include anxiety due to the cancer diagnosis, cancer-related pain, and the direct or indirect side effects of their cancer treatments (nausea, vomiting, or hot flashes) $[5,6]$. Sleep disturbances in individuals with cancer may be even more exacerbated in those with cancer-related fatigue, which is another common symptom in this population $[7,8]$. Similar to the general population with sleep disturbances, a pharmacological approach is typically one of the most common options for treating sleep disturbances in cancer survivors, especially in the acute stages $[9,10]$. But as sleep disturbances in cancer survivors are typically a chronic problem, non-pharmacological treatments may be beneficial as they will reduce the potential adverse outcomes associated with long-term pharmacological usage.

Cognitive behavioral therapy (CBT) is currently considered the non-pharmacological treatment of choice for sleep disturbances in many populations including cancer survivors $[11,12]$. Exercise is another non-pharmacological treatment with emerging systematic review-level evidence regarding its efficacy in improving sleep outcomes in cancer survivors [13, 14]. However, due to potential limitations in the accessibility and cost for supervised CBT and exercise therapy for cancer survivors living in rural/remote areas and/or with limited financial savings, there is a need to determine if therapies that have shown to be beneficial for improving sleep in other populations may also be beneficial in cancer survivors. Massage and relaxation therapy could both be examples of such nonpharmacological techniques that can improve sleep outcomes in other populations and may be more accessible to many cancer survivors than supervised CBT or exercise therapy sessions and utilized even in patients with advanced cancer.

Clinical massage refers to "the use of manual manipulation of the soft tissues to relieve specific complaints of pain and dysfunction" [15]. Swedish massage and deep tissue massage are the two most common forms of therapeutic massage, with Swedish massage more commonly used for relaxation [16] and deep tissue massage to alleviate pain [17]. Common techniques used within these massage forms may include effleurage, petrissage, percussion, myofascial release, trigger point therapy, deep transverse friction, compression massage, and cross-fiber massage. Therapeutic massage has shown to significantly improve rapid eye movement latency and stage 1 sleep and increase sleep stages 3 and 4 in postmenopausal women [18]. In patients with fibromyalgia, therapeutic massage significantly improved selfreported sleep quality [19]. Within cancer population, there is also a non-randomized controlled trial that suggests therapeutic massage is beneficial in reducing pain, boosting mood, and promoting relaxation in cancer survivors [20].
Relaxation therapy is another commonly practiced nonpharmacological treatment option that may be useful for the management of a variety of physical and psychosocial issues, including sleep disturbances. This form of therapy typically consists of breathing exercises, somatic relaxation, stretching and relaxing of the muscles in a continuous and systematic pattern to aid relaxation of the body and mind. Relaxation therapy given as a home program for patients with chronic obstructive pulmonary disease has shown to improve sleep quality [21]. Furthermore, a meta-analysis indicates that relaxation therapy has proven to be efficacious in cancer-related fatigue, especially during cancer treatment [22].

Though there are studies addressing massage and relaxation therapy for treatment of sleep disturbances in the adult and pediatric cancer population, there has been no systematic summary of the data available. Summarizing the findings of randomized control trials (RCTs) would be beneficial in developing treatment strategies for sleep disturbances in cancer survivors, during and after cancer treatment and in highlighting potential gaps in the literature that future research may look to examine. Therefore, this systematic review was performed to identify relevant RCTs to determine whether there is currently any evidence to support the use of therapeutic massage or relaxation therapy for improving sleep outcomes in cancer survivors.

\section{Methods}

\section{Search strategy}

A comprehensive data search was performed on PubMed, Scopus, Web of Science, PEDro, and CINAHL from inception to September 2020. The search terms used for cancer were the following: Carcinoma (MeSH), Cancer, Neoplasms (MeSH), Malignancy and Tumor. Sleep (MeSH), sleep quality, sleep disturbances, Insomnia, Sleep wake disorders (MeSH), Sleep initiation and maintenance disorders (MeSH) and Sleep disorders were the search terms related to sleep disturbance. For the interventions, Relaxation techniques, Relaxation therapy (MeSH) and Massage (MeSH) were the terms used. The search terms were combined with Boolean operator 'AND' or 'OR' wherever relevant. The reference list of the included articles was also screened for potentially relevant studies. The search was limited to RCTs involving human participants that were published in English.

\section{Selection of studies}

After the results from each database were compiled and duplicates removed, title and abstracts were screened independently by 2 reviewers (RG and PV). Any disagreements were sorted by discussion with SRS. The screening for eligible 
articles was done based on the pre-set criteria. To be included in the systematic review, studies had to (1) include cancer survivors of any ages, type of cancer, or treatment status; (2) have massage or relaxation therapy as the primary intervention; (3) include comparisons to usual care or active/sham treatments; (4) report self-reported or objectively measured sleep outcomes; and (5) involve RCT designs, with the results reported in peer-reviewed journals. Cancer survivors were defined according to the National Cancer Institute definition that states "a person is considered to be a survivor in cancer from the time of diagnosis until the end of life" [23]. Studies reporting any form of massage such as deep friction massage, Swedish massage, and its components used for therapeutic benefit were included in the review. Studies evaluating relaxation therapy techniques used independently, consisting of breathing exercises, somatic relaxation, and progressive relaxation techniques were included in the review. However, other forms of complimentary treatments that included relaxation therapy as a part of the treatment were excluded.

\section{Data extraction and management}

All the eligible studies were screened further based on full text independently by RG and PV. Any disagreements were sorted after discussion with SRS, VK, and JK. A data extraction template was developed for the eligible studies which included information on the demographic characteristics of the participants, description of the intervention, comparator, treatment status, and key findings. Data extraction was performed by RG and PV and disagreements were sorted by discussions with SRS, VK, and JK.

\section{Assessment of risk of bias}

The assessment of risk of bias for the included studies was performed independently by RG and PV using the Cochrane risk of bias tool [24]. The studies were scored under the domains of random sequence generation, allocation concealment, blinding of participants and personnel, blinding of outcome assessment, incomplete outcome data, selective reporting, and other bias. The judgment of yes was marked as low risk and no as high risk. Unclear was marked if the details were missing or unknown bias. Any disagreements in the markings between the 2 reviewers were sorted by discussions with SRS.

\section{Results}

\section{Characteristics of studies}

As seen in the PRISMA flowchart (Fig. 1), a total of 371 articles were retrieved from the data search (PubMed-77,
Scopus-159, Web of Science-78, CINAHL-2, and PEDro55). A total of 278 articles were screened based on title and abstract after removing the duplicates. Of the 22 articles that were found to be potentially eligible and underwent full-text screening, 7 articles which met the inclusion criteria were included in the review. The most common reasons for exclusion of the articles included non-randomized controlled trial methodologies and a lack of reported sleep outcomes.

\section{Risk of bias}

The summary of the risk of bias assessments of the included studies has been represented in Fig. 2a and b. Of the 4 massage therapy studies, a high risk of bias was reported for Incomplete Outcome Data [25] and Other Biases [26]; with unclear risk of bias reported for Random Sequence Generation [25, 27, 28], Allocation Concealment [23, 26-28], Blinding of Participants [25, 27], and Blinding of Outcome Assessment [25]. Of the 3 relaxation therapy studies, a high risk of bias was reported for Incomplete Outcome Data, Selective Reporting [29, 30], and Other Biases [29-31]; with unclear risk of bias reported for Allocation Concealment [29], Blinding of Participants [29], and Blinding of Outcome Assessment [29].

\section{Population of included studies}

Among the 7 included studies, 6 studies involved adults from 18 to 78 years $[25,27-30]$ and 1 involved pediatric population with an age range of $4-8$ years [31]. Four studies included participants with mixed type of cancers $[25,27,29,30], 3$ studies included participants with metastatic cancer $[25,28$, 29], and 2 studies included participants with leukemia [26, 31].

\section{Intervention of included studies}

Four out of 7 RCTs studied the effect of massage therapy [25-28], with the other 3 examining relaxation therapy [29-31] as their intervention. The total number of participants recruited for the 4 RCTs studying the effect of massage therapy was 205 , out of which 187 completed the entire study. There were 50 participants recruited across the 3 RCTs studying the effect of relaxation therapy, with 33 participants completing the study.

\section{Massage therapy}

The 4 included RCTs that studied the effect of massage therapy, delivered either by massage therapists or nurses trained in massage, are summarized in Table 1. The duration of the interventions ranged from 2 days to 4 weeks, involving 2 to 3 massage sessions per week, with each massage therapy 
Fig. 1 PRISMA flowchart describing the study selection process
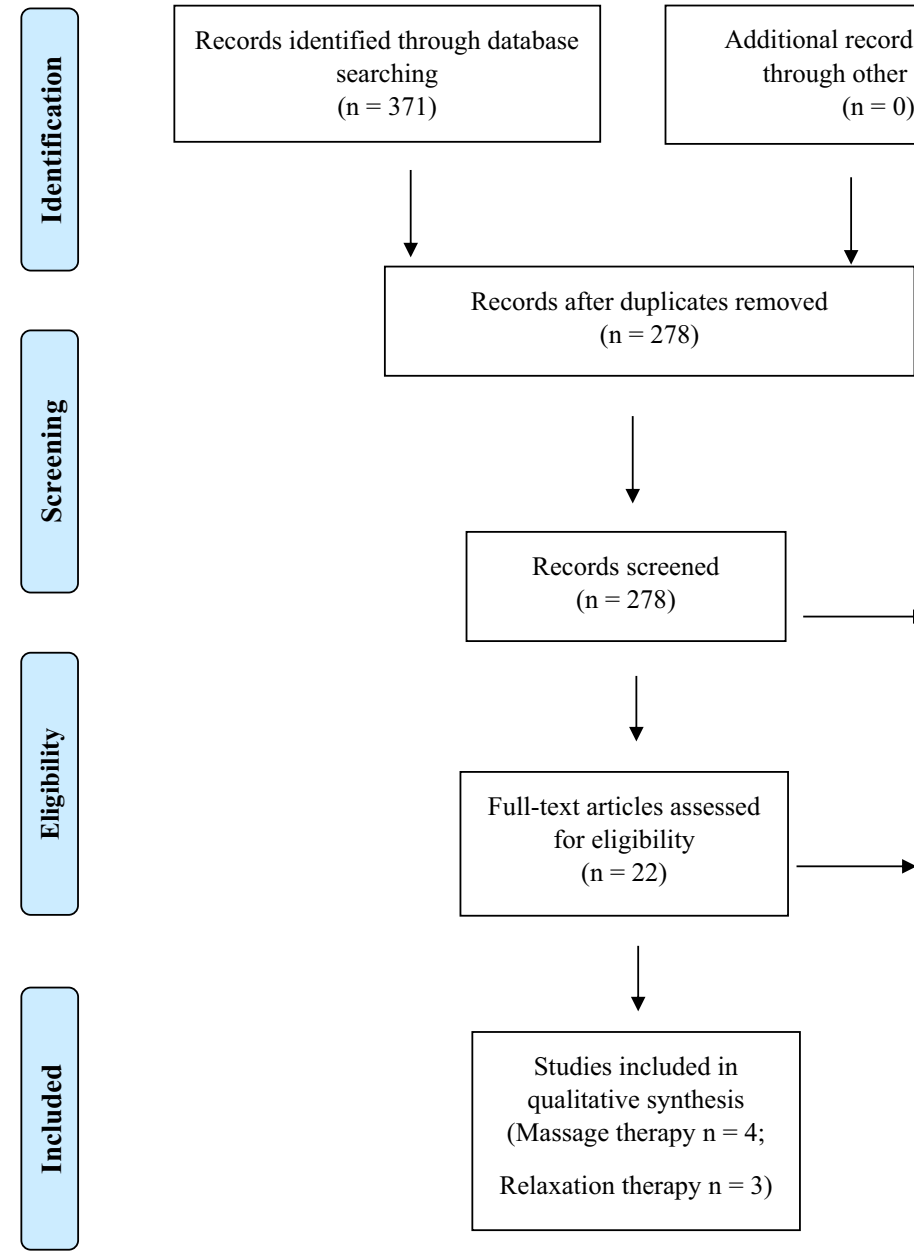

session ranging from 10 to $45 \mathrm{~min}$ in duration. Two studies compared the effect of massage with usual care [26, 27], 1 study compared the intervention to a social attention control [28], and the remaining study compared massage with usual care and no-touch control interventions [25]. One study used a MiniMotionlogger actigraph with sleep diary to objectively measure sleep [27], whereas the remaining 3 studies used self-reported questionnaires including the RichardsCampbell Sleep Questionnaire (RCSQ) and Pittsburg Sleep Quality Index (PSQI) to assess sleep quality [25, 26, 28].

Significant improvements in self-reported sleep quality were reported in 2 studies, with this including a significant between-group improvement in PSQI [26] and a trend for a significant between-group improvement in RCSQ $(p=0.07)$ after the first day of the massage intervention [28]. The only significant benefit observed for any objective sleep outcomes was reported in a study utilizing the Motionlogger device, whereby Jacobs et al. [27] observed a significant betweengroup increase in the number of nighttime long sleep episodes for the massage compared to the control group.

Feasibility of the massage interventions were reported in the studies conducted by Toth et al. and Jacobs et al. [25, 27].
Additional records identified through other sources $(\mathrm{n}=0)$

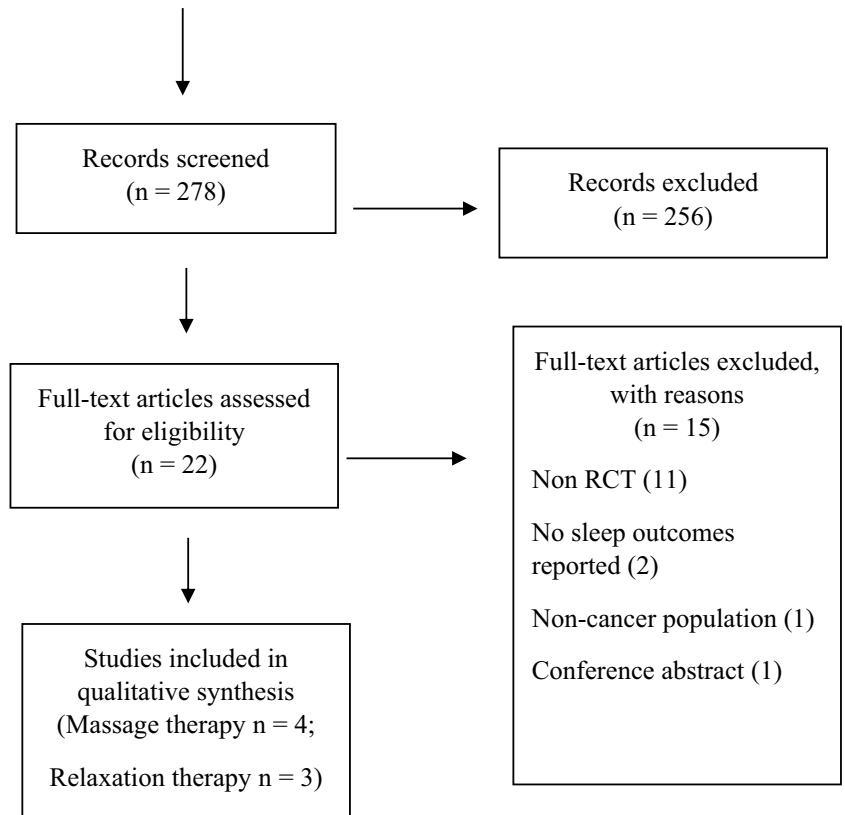

Toth et al. [25] reported that it was feasible to provide in-home massage therapy to the participants by professional massage therapists, with each participant averaging 2.8 sessions of the required 3 sessions during the 1-week trial. In the study of Jacobs et al. [27], the goal was for massage therapists to provide 2-3 massages to adolescent patients with cancers who were staying in the hospital for a minimum of 4 days. Results indicated reasonable feasibility, in that $94 \%$ of the participants received 1 massage and $69 \%$ received 2 massages during their hospital stay. While feasibility outcomes were not directly assessed in the other studies, some indication of the feasibility for the other 2 studies may be provided by comparing the number of participants initially recruited with the number of participants who completed the study. Of the 72 participants recruited in the study by Jane et al., 2 and 3 dropped out by the second session (T2) in the massage and social attention group, respectively [28]. In the study conducted by Miladinia et al., out of the 64 recruited participants, only 3 participants in the massage therapy group and 1 in the usual care group were lost to follow-up [26].

The safety of these massage interventions was examined by monitoring the number of adverse events in 2 of the 4 studies. 
Fig. 2 a Risk of bias of massage therapy studies. Green - low risk, yellow - unclear risk, and red high risk of bias. b Risk of bias of relaxation therapy studies a

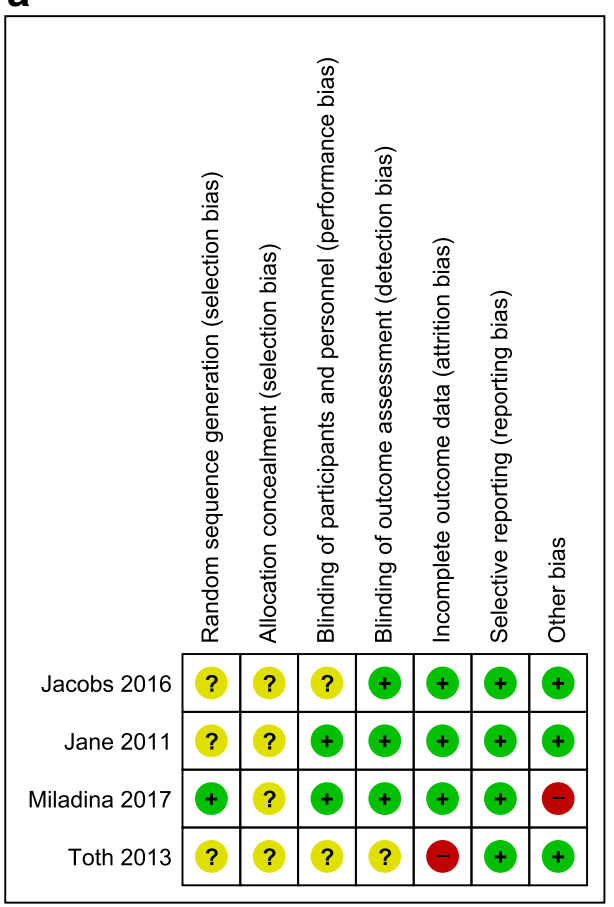

b

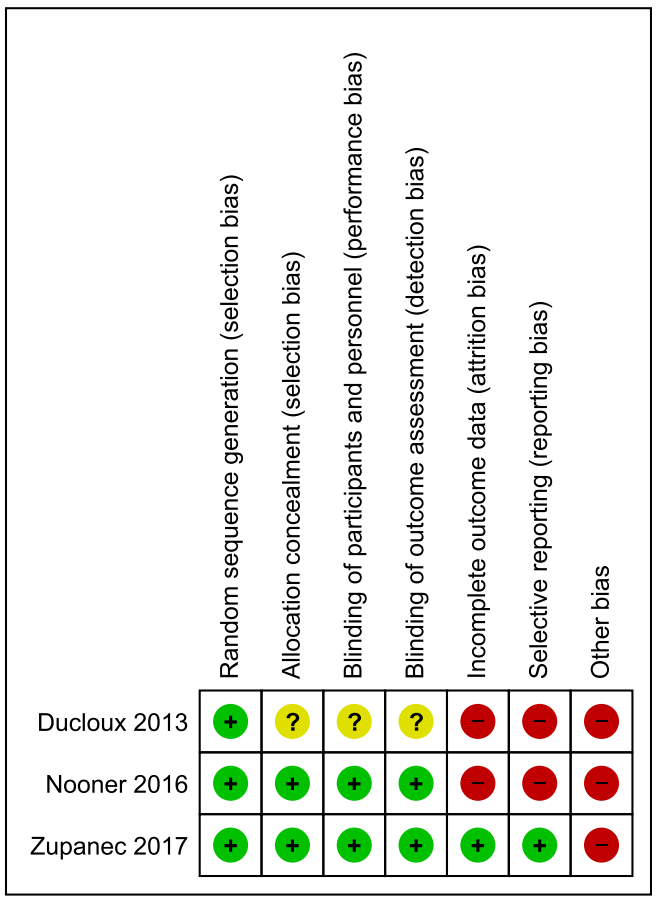

No adverse events related to the massage therapy were reported in either of these studies $[25,28]$.

\section{Relaxation therapy}

As summarized in Table 2, there were 3 RCTs that studied the effect of relaxation therapy on sleep disturbances in cancer populations [29-31]. All 3 RCTs were pilot studies with the duration of intervention lasting from 3 to 60 days that examined if a variety of sleep outcomes could be improved compared to usual care. Two out of the 3 studies provided some degree of relaxation guidance by the therapist, with 1 study appearing to only provide relaxation resources and written instructions [30]. The outcome tools used 3 self-reported questionnaires including the Numerical Rating Scale of Satisfaction of Sleep (NRSSS), Patient-Reported Outcomes Measurement Information System (PROMIS), and the Children Sleep Habits Questionnaire (CSHQ) as well as objective sleep data from the accelerometers including the Minimotionlogger actigraph.

No statistically significant improvements were observed in any sleep outcomes as a result of relaxation therapy, although there were some potential trends observed. Specifically, a trend for significant improvements in self-reported sleep quality was observed after the second day of relaxation training as assessed by the NRSSS [29], although no exact $p$ value was provided. Sleep disturbances, as assessed by the PROMIS, were also concluded to have been improved by the authors in 2 of the 3 participants in the relaxation group and in 1 of the 3 participants in the relaxation plus guided imagery groups in the case series by Nooner et al. [30]. The authors also stated that all but 1 of these participants reported more refreshing sleep and fewer sleep symptoms after 30 days of relaxation therapy [30]. However, it must be acknowledged that none of these improvements in the Nooner et al. [30] study appears to have undergone statistical comparisons. Of the 7 objective sleep outcomes assessed using an actigraph by Zupanec et al. [31], there was a trend for an improvement in the wake time after sleep onset $(p=0.08)$ for the relaxation compared to the usual care group.

Feasibility data for relaxation therapy was provided by Zupanec et al. [32]. The 8 participant families (childhood cancer survivor and their parents) who completed the study rated the education session to be somewhat or very useful, with the sleep tips as well as the relaxation books and associated techniques reported to be the major resources used [31]. The major barriers faced related to the children's (1) fatigue levels being so high that daytime naps were still required, with such naps potentially negatively affecting the time required for implementing the relaxation intervention; late-night medication interfering with early bedtimes; and (3) resistance to reading the same relaxation book every day [31]. Although feasibility was not directly assessed in the remaining studies, some indication of the feasibility of these interventions may also be provided by examining the number of participants who started and completed each of the relaxation therapy programs. For example, Ducloux et al. [29] recruited 9 participants into both their immediate and delayed intervention groups, with 7 participants completing the immediate intervention but only 4 completing the delayed intervention. Twenty participants 
Table 1 Summary of massage therapy studies

\begin{tabular}{|c|c|c|c|c|c|c|c|}
\hline \multirow[t]{2}{*}{ Reference } & \multicolumn{3}{|l|}{ Sample } & \multicolumn{2}{|l|}{ Intervention details } & \multicolumn{2}{|l|}{ Results } \\
\hline & $\begin{array}{l}\text { Cancer type } \\
\text { and stage }\end{array}$ & $\begin{array}{l}\text { Age, sex, and } \\
\text { sample size }\end{array}$ & $\begin{array}{l}\text { Cancer treatment } \\
\text { and sleep disorder } \\
\text { status }\end{array}$ & Description & $\begin{array}{l}\text { Duration } \\
\text { and } \\
\text { frequency }\end{array}$ & Pre & Post \\
\hline \multirow[t]{2}{*}{$\begin{array}{l}\text { Jane et al. } 2011 \\
\text { [28], } \\
\text { Taoyuan, } \\
\text { Taiwan }\end{array}$} & \multirow[t]{2}{*}{$\begin{array}{l}\text { Mixed cancer } \\
\text { type, stage } \\
4 \text { patients } \\
\text { with } \\
\text { metastatic } \\
\text { bone cancer }\end{array}$} & $\begin{array}{l}50.1 \pm 11.5 \mathrm{yr} \\
(15 \mathrm{M}, 21 \mathrm{~F})\end{array}$ & $\begin{array}{l}\text { Cancer treatment: } \\
\text { completed } \\
\text { primary } \\
\text { treatment, with } \\
56 \% \text { under } \\
\text { palliative care; }\end{array}$ & $\begin{array}{l}\text { Effleurage, light petrissage, } \\
\text { compression, and nerve } \\
\text { stroke to total body, } \\
\text { provided by cancer } \\
\text { nurses with } 3 \text { months of } \\
\text { massage training. }\end{array}$ & $\begin{array}{l}45 \text { min for } \\
3 \text { days }\end{array}$ & $\begin{array}{l}\text { RCSQ (T1): } \\
22.1 \pm 15.1\end{array}$ & $\begin{array}{l}\text { RCSQ (T3): } \\
32.8 \pm 11.4^{\#}\end{array}$ \\
\hline & & $\begin{array}{l}49.7 \pm 9.7 \mathrm{yr} \\
(15 \mathrm{M}, 21 \mathrm{~F})\end{array}$ & $\begin{array}{l}\text { sleep disorder: } \\
\text { not stated }\end{array}$ & $\begin{array}{l}\text { Social attention } \\
\text { encouraging participants } \\
\text { to express feelings or } \\
\text { concerns about admission } \\
\text { involving the presence of } \\
\text { a caring therapist }\end{array}$ & & $\begin{array}{l}\text { RCSQ (T1): } \\
25.1 \pm 13.6\end{array}$ & $\begin{array}{l}\text { RCSQ (T3): } \\
30.2 \pm 14.4\end{array}$ \\
\hline \multirow[t]{3}{*}{$\begin{array}{l}\text { Toth et al. } \\
2013 \text { [25], } \\
\text { Boston, USA }\end{array}$} & \multirow[t]{3}{*}{$\begin{array}{l}\text { Mixed (stage } \\
\text { 4) patients } \\
\text { with } \\
\text { metastatic } \\
\text { cancer }\end{array}$} & $\begin{array}{l}54.9 \pm 12 \mathrm{yr} \\
(3 \mathrm{M}, 17 \mathrm{~F})\end{array}$ & $\begin{array}{l}\text { Cancer treatment: } \\
\text { not stated; } \\
\text { Sleep disorder: not } \\
\text { stated. }\end{array}$ & $\begin{array}{l}\text { Swedish and non-Swedish } \\
\text { massage techniques in- } \\
\text { cluding gliding/- } \\
\text { effleurage, light } \\
\text { petrissage, compression, } \\
\text { and nerve stroke to } \\
\text { non-metastatic areas pro- } \\
\text { vided by professional } \\
\text { massage therapists }\end{array}$ & \multirow[t]{3}{*}{$\begin{array}{l}15-45 \mathrm{~min} / \\
\text { day, } 3 \\
\text { daysa } \\
\text { week for } \\
1 \text { week }\end{array}$} & & $\begin{array}{l}\text { RCSQ CS (1 week): } \\
-3.5(-9,0) \text { RCSQ } \\
\text { CS }(1 \text { month): } \\
-4(-12,0)\end{array}$ \\
\hline & & $\begin{array}{l}54.9 \pm 10 \mathrm{yr} \\
(1 \mathrm{M}, 9 \mathrm{~F})\end{array}$ & & $\begin{array}{l}\text { No-touch control provided } \\
\text { by professional massage } \\
\text { therapists with hands } \\
12 \text { in. }(30 \mathrm{~cm}) \text { above } \\
\text { participants but with no } \\
\text { healing intention }\end{array}$ & & & $\begin{array}{l}\text { RCSQ CS }(1 \text { week }): \\
0(-7,9) \\
\text { RCSQ CS }(1 \\
\quad \text { month }) \\
0(-12,10)\end{array}$ \\
\hline & & $\begin{array}{l}55.6 \pm 9 \mathrm{yr} \\
(3 \mathrm{M}, 6 \mathrm{~F})\end{array}$ & & $\begin{array}{l}\text { Usual care participants } \\
\text { received no visits from } \\
\text { massage therapists }\end{array}$ & & & $\begin{array}{l}\text { RCSQ CS }(1 \text { week }): \\
-0.5(-4,1) \\
\text { RCSQ CS }(1 \\
\text { month): } \\
0(-15,12)\end{array}$ \\
\hline \multirow[t]{2}{*}{$\begin{array}{l}\text { Jacobs et al. } \\
2016 \text { [27], } \\
\text { Washington, } \\
\text { USA }\end{array}$} & \multirow[t]{2}{*}{$\begin{array}{l}\text { Mixed type } \\
\text { and stage } \\
\text { with at least } \\
4 \text { days of } \\
\text { hospitaliza- } \\
\text { tion }\end{array}$} & $\begin{array}{l}15.5 \pm 2.6 \mathrm{yr} \\
(12 \mathrm{M}, 4 \mathrm{~F})\end{array}$ & $\begin{array}{l}\text { Cancer treatment: } \\
70 \% \text { receiving } \\
\text { chemotherapy. } \\
\text { Sleep disorder: not } \\
\text { stated. }\end{array}$ & $\begin{array}{l}\text { Swedish massage of the } \\
\text { total body by massage } \\
\text { therapists }\end{array}$ & \multirow[t]{2}{*}{$\begin{array}{l}20-30 \\
\min / \text { day } \\
\text { for } 2-3 \\
\text { days }\end{array}$} & $\begin{array}{l}\begin{array}{l}\text { Pre- } \\
\quad \text { outcome } \\
\text { mean) }\end{array} \\
\text { SMN: } 366 \\
\text { SEN: } 59 \\
\text { WM: } 259 \\
\text { WE :18 } \\
\text { LSE: } 11 \\
\text { 24SM: } 391 \\
\text { 24SE: } 13\end{array}$ & $\begin{array}{l}\text { Post- (outcome } \\
\text { mean) } \\
\text { SMN: } 419 \\
\text { SEN: } 64 \\
\text { WM: } 258 \\
\text { WE: } 19 \\
\text { LSE: } 12 * \\
\text { 24SM: } 444 \\
\text { 24SE: } 17\end{array}$ \\
\hline & & $\begin{array}{l}16 \pm 2.5 \mathrm{yr} \\
(12 \mathrm{M}, 6 \mathrm{~F})\end{array}$ & & $\begin{array}{l}\text { Usual care received no } \\
\text { special treatment other } \\
\text { than the primary } \\
\text { chemotherapy treatment. }\end{array}$ & & $\begin{array}{l}\text { SMN: } 379 \\
\text { SEN: } 63 \\
\text { WM: } 247 \\
\text { WE: } 20 \\
\text { LSE: } 13 \\
\text { 24SM: } 431 \\
\text { 24SE: } 18\end{array}$ & $\begin{array}{l}\text { SMN: } 365 \\
\text { SEN: } 67 \\
\text { WM: } 194 \\
\text { WE: } 16 \\
\text { LSE : } 11 \\
\text { 24SM: } 401 \\
\text { 24SE: } 16\end{array}$ \\
\hline $\begin{array}{l}\text { Miladina et al. } \\
2017 \text { [26], } \\
\text { Alwaz, Iran }\end{array}$ & $\begin{array}{l}\text { Acute } \\
\text { leukemia } \\
\text { undergoing } \\
\text { chemother- } \\
\text { apy }\end{array}$ & $\begin{array}{l}33.9 \pm 9.6 \mathrm{yr} \\
(16 \mathrm{M}, 14 \mathrm{~F})\end{array}$ & $\begin{array}{l}\text { Cancer treatment: } \\
\text { chemotherapy; } \\
\text { Sleep disorder: } \geq 3 \\
\text { on Numerical } \\
\text { Rating Scale and } \\
>5 \text { on PSQI }\end{array}$ & $\begin{array}{l}\text { Slow-stroke back massage } \\
\text { involving circular, } \\
\text { sweeping hand strokes } \\
\text { extending from the skull } \\
\text { to sacrum by oncology } \\
\text { nurses with } 4 \text { months of } \\
\text { massage training. }\end{array}$ & $\begin{array}{l}10 \\
\text { min/day, } \\
3 \text { days a } \\
\text { week for } \\
4 \text { weeks }\end{array}$ & $\begin{array}{l}\text { PSQI Pre: } \\
12.23 \pm \\
3.75\end{array}$ & $\begin{array}{l}\text { PSQI Post: } \\
9.70 \pm 3.27^{*}\end{array}$ \\
\hline
\end{tabular}


Table 1 (continued)

\begin{tabular}{|c|c|c|c|c|c|c|c|}
\hline \multirow[t]{2}{*}{ Reference } & \multicolumn{3}{|l|}{ Sample } & \multicolumn{2}{|l|}{ Intervention details } & \multicolumn{2}{|l|}{ Results } \\
\hline & $\begin{array}{l}\text { Cancer type } \\
\text { and stage }\end{array}$ & $\begin{array}{l}\text { Age, sex, and } \\
\text { sample size }\end{array}$ & $\begin{array}{l}\text { Cancer treatment } \\
\text { and sleep disorder } \\
\text { status }\end{array}$ & Description & $\begin{array}{l}\text { Duration } \\
\text { and } \\
\text { frequency }\end{array}$ & Pre & Post \\
\hline & & \multicolumn{2}{|l|}{$(15 \mathrm{M}, 15 \mathrm{~F})$} & $\begin{array}{l}\text { Usual care routine nursing } \\
\text { and medical care }\end{array}$ & & \multicolumn{2}{|l|}{$\begin{array}{c}12.10 \pm \\
3.45\end{array}$} \\
\hline \multicolumn{8}{|c|}{$\begin{array}{l}C S \text { change score, } F \text { females, } L S E \text { long sleep episodes at nighttime, } M \text { males, } P S Q I \text { Pittsburgh Sleep Quality Index, } R C S Q \text { Richards-Campbell Sleep } \\
\text { Questionnaire, } S E N \text { sleep efficiency at nighttime, } S M N \text { sleeping minutes at nighttime, } t 1 \text { first session, } t 3 \text { third session, } W E \text { wake episodes during sleep at } \\
\text { nighttime, } W M \text { wake min after sleep onset at nighttime, } y r \text { years, } 24 S E \text { long sleep episodes through whole day, } 24 S M \text { sleeping minutes through the whole } \\
\text { day }\end{array}$} \\
\hline
\end{tabular}

were randomized to the Nooner et al. study. Nine of the 11 relaxation therapy participants and all 9 usual care participants completed the study [30]. In contrast, of the 3 participants allocated to the each of the 4 groups (relaxation, guided imagery, relaxation and guided imagery, and usual care), the relaxation group maintained only 2 participants at 30 days and 1 participant at 60 days, compared to the combined relaxation and guided imagery group who maintained 2 participants at 30 and 60 days. The dropouts in the study of Nooner et al. [30] were attributed to death, loss to follow-up due to complications of treatment, and patient request. The reasons that contributed to some participants discontinuing the Nooner et al. [30] study were described in a participant evaluation of the study. Specifically, the negative perceptions of the intervention that may have increased dropout rates were that the relaxation program may have been "too much to keep up" during complicated periods of cancer treatment and that completing the symptom log was too much work.

There appeared to be no monitoring of adverse events in any of the 3 relaxation therapy studies [29-31].

\section{Discussion}

Cancer survivors are at a higher risk of suffering from cancerrelated fatigue and sleeping disorders than members of the general population [3]. Currently, cancer survivors experiencing sleep disturbances generally undergo pharmacological treatment, with such an approach having other potential side effects [33]. The side effects of pharmacotherapy in management of sleep include drowsiness, grogginess, inability to concentrate, and difficulty in managing work and social relationships [34]. While systematic review-level evidence indicates that CBT [11] and exercise [13] are non-pharmacological treatments that can improve sleep outcomes in cancer survivors, not all cancer survivors may be interested or able to access supervised CBT or exercise therapy sessions to improve their sleep. Therefore, cancer survivors and clinicians could benefit from more evidence regarding the potential use of other non-pharmacological techniques for the management of sleep disorders.

Within the current review, 2 of the 4 studies involving massage therapy, as provided by certified therapists, observed statistically significant self-reported sleep quality (PSQI) or objective improvements in sleep outcomes (number of long sleep episodes) in cancer survivors, consistent with the findings reported for postmenopausal women and patients with fibromyalgia [18, 19]. Such improvements in sleep outcomes for cancer survivors might be of major clinical benefit, as the duration of massage therapy provided was comparatively shorter when compared to the other non-pharmacological interventions like exercise and CBT $[13,35]$. Within the 4 massage therapy studies included in this review, there was relative heterogeneity in the cancer survivors as well as the type, frequency, and duration of massage therapies provided. While such variation in the massage therapy might be required to avoid massaging the tumor or metastasis sites, the heterogeneity in interventions provided make it difficult to provide any clear clinical guidelines on the optimal type, frequency, and duration of massage therapy required to improve sleep outcomes in cancer survivors. Nevertheless, the findings of this review suggest that a minimal dose of 90-120 min (be it spread out across 3 days or several weeks) of massage therapy provided by massage therapists can produce some significant benefits in sleep quality as reported by PSQI and sleep episodes as measured by accelerometers in cancer survivors. However, due to the short study duration and lack of followup data, the long-term effects of massage therapy in improving sleep outcomes in cancer survivors are virtually unknown.

Massage therapy, be it delivered at the cancer survivor's home by a travelling massage therapist or within the hospital setting, appears to be quite feasible within the research studies reviewed, with most of the planned massage therapy sessions being completed and with relatively small rates of participant 
Table 2 Summary of relaxation therapy studies

\begin{tabular}{|c|c|c|c|c|c|c|c|c|}
\hline \multirow[t]{2}{*}{ Reference } & \multicolumn{3}{|l|}{ Sample } & \multicolumn{2}{|l|}{ Intervention details } & \multicolumn{3}{|l|}{ Results } \\
\hline & $\begin{array}{l}\text { Cancer type } \\
\text { and stage }\end{array}$ & $\begin{array}{l}\text { Age, sex } \\
\text { and } \\
\text { sample } \\
\text { size }\end{array}$ & $\begin{array}{l}\text { Cancer } \\
\text { treatment and } \\
\text { sleep disorder } \\
\text { status }\end{array}$ & Description & $\begin{array}{l}\text { Duration } \\
\text { and } \\
\text { frequency }\end{array}$ & Pre & Mid & Post \\
\hline \multirow[t]{2}{*}{$\begin{array}{l}\text { Ducloux et al. } \\
\text { 2012[29], } \\
\text { Geneva, } \\
\text { Switzerland }\end{array}$} & \multirow[t]{2}{*}{$\begin{array}{l}\text { Mixed (stage } \\
\text { 4) with } \\
\text { metastatic } \\
\text { cancer and } \\
\text { estimated } \\
\text { prognosis } \\
<6 \text { months }\end{array}$} & $\begin{array}{l}61 \pm 15 \mathrm{yr} \\
(3 \mathrm{M}, 6 \mathrm{~F})\end{array}$ & \multirow[t]{2}{*}{$\begin{array}{l}\text { Cancer } \\
\text { treatment: } \\
\text { not stated; } \\
\text { Sleep disorder: } \\
\text { diagnosed } \\
\text { using ICSD } \\
\text { criteria. }\end{array}$} & $\begin{array}{l}\text { Immediate } \\
\text { intervention: } \\
\text { Deep breathing } \\
\text { exercises, } \\
\text { somatic tension } \\
\text { release was } \\
\text { taught by a } \\
\text { specialized } \\
\text { nurse with } \\
\text { certification in } \\
\text { relaxation. An } \\
\text { audio recording } \\
\text { of the program } \\
\text { on CD was } \\
\text { provided to the } \\
\text { participants to } \\
\text { use prior to } \\
\text { nighttime sleep. }\end{array}$ & \multirow[t]{2}{*}{$\begin{array}{r}1 \mathrm{~h} / \text { day } \\
\text { for } 3 \\
\text { days }\end{array}$} & $\begin{array}{l}\text { NRSSS } \\
\text { day } 1: \\
6.1+2.4\end{array}$ & $\begin{array}{l}\text { NRSSS } \\
\text { day } 2: \\
3.6 \pm 2.3\end{array}$ & $\begin{array}{l}\text { NRSSS } \\
\text { day } 5: \\
4.0 \pm 2.3\end{array}$ \\
\hline & & $\begin{array}{l}66 \pm 12 \mathrm{yr} \\
(3 \mathrm{M}, 6 \mathrm{~F})\end{array}$ & & $\begin{array}{l}\text { Delayed } \\
\text { intervention: as } \\
\text { above, but } \\
\text { started } 3 \text { days } \\
\text { after the } \\
\text { immediate } \\
\text { intervention } \\
\text { group. }\end{array}$ & & $6.5+2.2$ & $4.0 \pm 2.1$ & $3.8 \pm 2.3$ \\
\hline \multirow[t]{5}{*}{$\begin{array}{c}\text { Nooner et al. } \\
2016 \text { [30], } \\
\text { OK, USA }\end{array}$} & \multirow[t]{5}{*}{$\begin{array}{l}\text { Hematologic } \\
\text { malignan- } \\
\text { cies or solid } \\
\text { tumors, } \\
\text { undergoing } \\
\text { chemother- } \\
\text { apy or prior } \\
\text { to HSCT }\end{array}$} & \multirow[t]{5}{*}{$\begin{array}{l}45 \pm 18 \mathrm{yr} \\
(6 \mathrm{M}, 5 \mathrm{~F})\end{array}$} & \multirow[t]{5}{*}{$\begin{array}{l}\text { Cancer } \\
\text { treatment: } \\
\text { chemothera- } \\
\text { py and } \\
\text { pre-HSCT } \\
\text { therapy; } \\
\text { Sleep disorder: } \\
\text { not stated. }\end{array}$} & $\begin{array}{l}\text { Guided imagery: } \\
\text { 19-min audio } \\
\text { program-- } \\
\text { morning } \\
\text { exercise, which } \\
\text { guides the } \\
\text { listener through } \\
\text { waking in the } \\
\text { morning. }\end{array}$ & \multirow[t]{5}{*}{$\begin{array}{l}19 \text { to } 39 \\
\mathrm{~min} /- \\
\text { day for } \\
60 \text { days }\end{array}$} & $\begin{array}{c}\text { PROMIS sleep } \\
\text { baseline: } \\
\text { Pt.5: } 23 / 40 \\
\text { Pt.7: } 19 / 40 \\
\text { Pt.9: } 25 / 40\end{array}$ & $\begin{array}{l}\text { PROMIS } \\
\text { sleep } \\
\text { day } 30: \\
21 / 40 \\
17 / 40 \\
29 / 40\end{array}$ & $\begin{array}{l}\text { PROMIS sleep } \\
\quad \text { day } 60: \\
- \\
20 / 40 \\
-\end{array}$ \\
\hline & & & & Relaxation: & & Pt.2: $25 / 40$ & $20 / 40$ & $26 / 40$ \\
\hline & & & & $\begin{array}{l}\text { 39-min audio } \\
\text { program guide } \\
\text { to serenity } \\
\text { which guided } \\
\text { the listener } \\
\text { through a } \\
\text { 10-point } \\
\text { system of } \\
\text { progressive } \\
\text { relaxation. }\end{array}$ & & $\begin{array}{l}\text { Pt.3: } 35 / 40 \\
\text { Pt.10: } 27 / 40\end{array}$ & $\begin{array}{l}- \\
-\end{array}$ & $\begin{array}{l}- \\
-\end{array}$ \\
\hline & & & & $\begin{array}{l}\text { Relaxation }+ \\
\text { guided imagery } \\
\text { - received both. }\end{array}$ & & $\begin{array}{l}\text { Pt.1: } 28 / 40 \\
\text { Pt.8: } 25 / 40 \\
\text { Pt.12: } 17 / 40\end{array}$ & $\begin{array}{l}- \\
22 / 40 \\
21 / 40\end{array}$ & $\begin{array}{l}- \\
20 / 40 \\
19 / 40\end{array}$ \\
\hline & & & & $\begin{array}{l}\text { Usual care: } \\
\text { received usual } \\
\text { medical care } \\
\text { but were given } \\
\text { relaxation } \\
\text { video resources } \\
\text { used in the }\end{array}$ & & $\begin{array}{l}\text { Pt.4: } 22 / 40 \\
\text { Pt.6: - } \\
\text { Pt.11: } 20 / 40\end{array}$ & $\begin{array}{l}21 / 40 \\
- \\
-\end{array}$ & $\begin{array}{l}- \\
- \\
-\end{array}$ \\
\hline
\end{tabular}


Table 2 (continued)

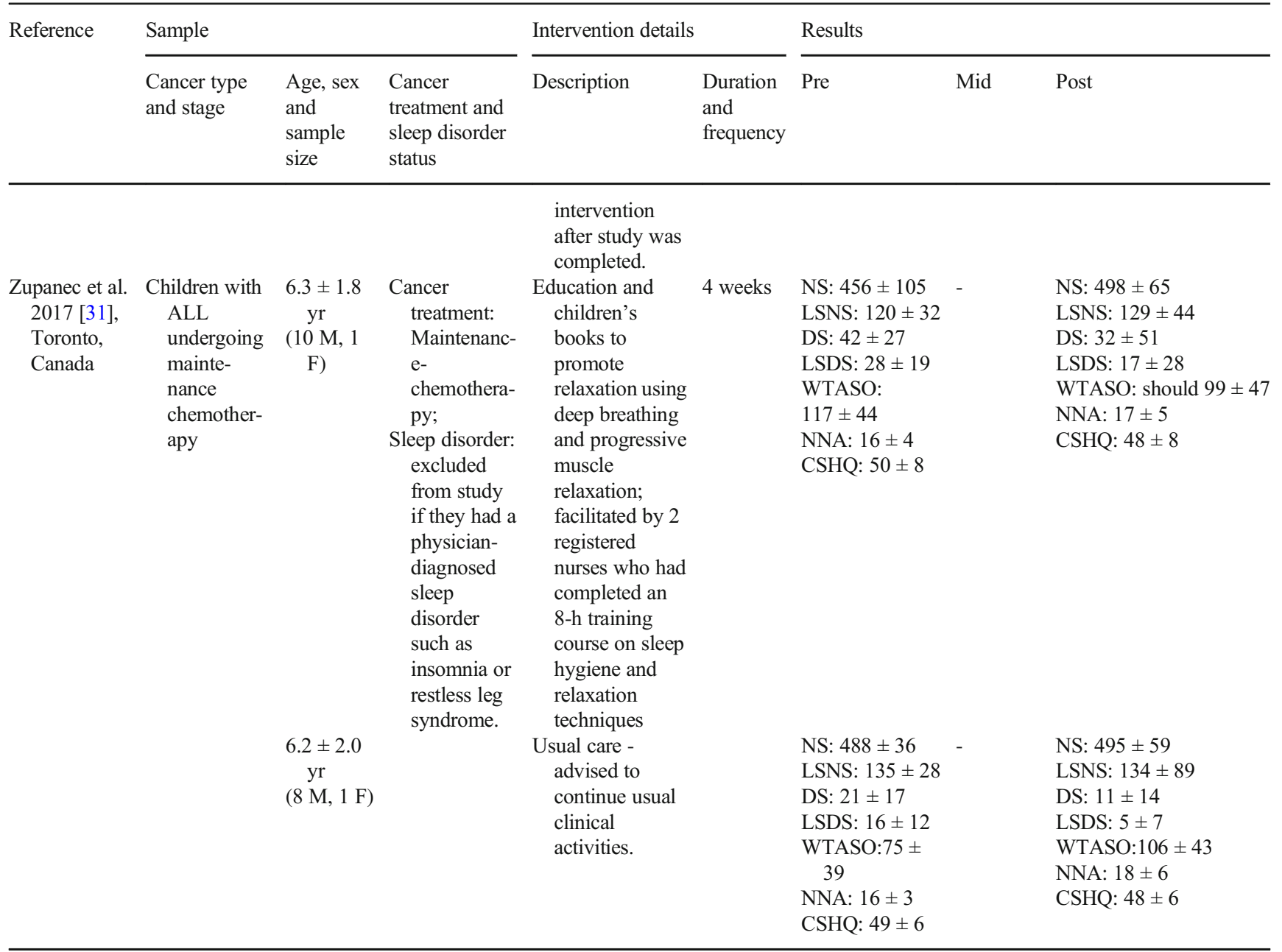

$A L L$ acute lymphoblastic leukemia, CSHQ Children sleep habits questionnaire, $D S$ Daytime sleep, $F$ females, ICSD International Classification of Sleep Disorders, LSDS longest stretch of daytime sleep, LSNS longest stretch of nighttime sleep, $M$ males, NNA number of nighttime awakenings, NRSSS Numerical Rating Scale of Satisfaction of Sleep, NS Nighttime sleep, PROMIS Patient-Reported Outcomes Measurement Information System, Pt participant, WTASO wake time after sleep onset, $y r$ years

$\square$ No face-to-face therapist guidance appeared to be provided to the intervention participants

dropout [25-28]. However, it is unclear what proportion of cancer survivors would be able to pay for ongoing massage therapy appointments or whether the cancer survivors' family, friends, or caregivers may be sufficiently trained to provide free and effective massage therapy to these individuals.

Among the 3 studies which studied relaxation therapy, there were no statistically significant improvements in any self-reported or objective sleep outcomes for the relaxation compared to control groups. However, there were trends for significant improvements in self-reported sleep quality, as assessed by the NRSSS [29] and for Actigraph recorded wake time after sleep onset [31]. Nooner et al. [30] also stated that all but 1 of the participants receiving relaxation training reported more refreshing sleep and fewer sleep symptoms, although no statistical data was actually provided to support these comments. The lack of significant improvements in sleep outcomes within the 3 relaxation therapy studies may have reflected a variety of between-study differences in the interventions or baseline characteristics of the participants. The relative lack of significant benefit of the relaxation therapy studies may have also been a reflection of the relatively high dropout rates in the studies. For example, while Zupanec et al. [32] described how the childhood cancer survivors and their parents thought that a number of the relaxation therapy resources and sleep tips were beneficial, they also reported many barriers such as the child's nighttime medications and reluctance to read the same book every day to the ongoing implementation of this intervention with their children. The lack of ongoing face-to-face or telephone support of these programs by psychologists or psychiatrists and the resultant inability to tailor the relaxation therapy techniques to the individual participants' requirements and preferences may have 
been some of the reasons for the relatively poor adherence and lack of significant improvements in sleep outcomes. Such views appear consistent with the wider literature on the barriers to the successful and effective utilization of relaxation therapy in clinical populations $[36,37]$. Therefore, among the 7 RCTs examined, there appeared to be more support for massage therapy than relaxation therapy for improving sleep outcomes in cancer survivors. However, these preliminary conclusions require more published trials before any definitive conclusions can be drawn.

\section{Strengths and limitations}

To the best of our knowledge, this is the first systematic review summarizing the effect of massage or relaxation therapy for sleep disturbances in cancer survivors. We used a list of comprehensive search terms developed by in-depth search and discussions among the review team, and the search was run on a wide range of databases including PEDro which is specifically for physiotherapy interventions. The observation that some of the reviewed studies consisting of participants with metastatic cancer obtained some significant benefits in sleep outcomes was of interest, as there appears to be no current RCT-level evidence regarding the effectiveness of other non-pharmacological interventions for improving sleep outcomes in cancer survivors with metastatic cancer. Furthermore, the inclusion of self-reported sleep outcomes that provided insight into the patients' perspective was also considered a strength of the studies included in this review.

The limitations of this review process include restriction of articles to English and also the exclusion of gray literature. Unfortunately, there are also many limitations of the literature that were included in the review. Several of the included studies, especially those examining relaxation therapy, were unable to be described as low risk of bias due to the missing information reported regarding selection, performance, and detection bias. Many of the studies also did not provide detailed information regarding the actual massage or relaxation therapy intervention, which then may make replication of the intervention by practitioners or other researchers difficult. We also acknowledge that the included studies typically involved a small number of participants, cancer types, stages of cancer, and current treatments, with only one of the studies having inclusion criteria specifying that all participants needed to have been diagnosed with a sleep disorder by the International Classification of Sleep Disorders definition. With respect to the sleep outcomes, while there were some objective outcomes provided via accelerometry-derived data, such measures are indirect and not an example of outcomes recommended to be used in insomnia research and clinical practice [38]. Some relaxation therapy studies had a high dropout rate, which suggests there may be some issues in the widespread uptake of this therapy in cancer survivors.
Furthermore, as many studies utilized a relatively large number of sleep outcomes but at best only found significant improvements in a small subset of these outcomes, there exists the potential for type I errors to have occurred. Finally, none of these studies utilized a follow-up period to assess the length of time the treatment effects may last post-therapy.

\section{Conclusion}

The results of this systematic review provide some preliminary peer-reviewed support for the potential effectiveness and feasibility of massage therapy in both adult and pediatric cancer survivor populations. In contrast, the lack of statistically significant relaxation therapy-related improvements in cancer survivors' sleep outcomes and the relatively high dropout rates in the studies included are unable to provide any evidence-based support for this therapy for cancer survivors. The results of this systematic review when viewed with respect to the limitations of the included studies would suggest that CBT and perhaps exercise should remain as the 2 primary non-pharmacological treatments for improving sleep outcomes in cancer survivors. Therefore, future massage and relaxation therapy research should look to minimize the potential risk of biases of the study designs; involve larger sample sizes of a variety of demographic groups (e.g., age, sex, countries, or cultural groups), cancer types, and treatment options; utilize more direct sleep outcomes as advocated by the Australian Sleep Association [38]; and compare the potential benefits of these therapies to more established treatments such as CBT. As relaxation therapy may also be a component of CBT, it may also be useful to design studies that are able to quantify the unique contribution of relaxation within $\mathrm{CBT}$ and other mind-body interventions for improving sleep outcomes in cancer survivors.

Funding Open access funding provided by Manipal Academy of Higher Education, Manipal.

\section{Compliance with ethical standards}

Conflict of interest Justin Keogh is an Associate Editor for the Journal of Cancer Survivorship. The other authors declare that they have no conflict of interest.

Open Access This article is licensed under a Creative Commons Attribution 4.0 International License, which permits use, sharing, adaptation, distribution and reproduction in any medium or format, as long as you give appropriate credit to the original author(s) and the source, provide a link to the Creative Commons licence, and indicate if changes were made. The images or other third party material in this article are included in the article's Creative Commons licence, unless indicated otherwise in a credit line to the material. If material is not included in the article's Creative Commons licence and your intended use is not permitted by statutory regulation or exceeds the permitted use, you will need to obtain 
permission directly from the copyright holder. To view a copy of this licence, visit http://creativecommons.org/licenses/by/4.0/.

\section{References}

1. Strollo SE, Fallon EA, Gapstur SM, Smith TG. Cancer-related problems, sleep quality, and sleep disturbance among long-term cancer survivors at 9-years post diagnosis. Sleep Med. 2020;65: 177-85. https://doi.org/10.1016/j.sleep.2019.10.008.

2. Schmidt ME, Wiskemann J, Steindorf K. Quality of life, problems, and needs of disease-free breast cancer survivors 5 years after diagnosis. Qual Life Res. 2018;27(8):2077-86. https://doi.org/10. 1007/s11136-018-1866-8.

3. Fiorentino L, Rissling M, Liu L, Ancoli-Israel S. The symptom cluster of sleep, fatigue and depressive symptoms in breast cancer patients: severity of the problem and treatment options. Drug Discov Today Dis Model. 2011;8(4):167-73. https://doi.org/10. 1016/j.ddmod.2011.05.001.

4. Irwin MR, Olmstead RE, Ganz PA, Haque R. Sleep disturbance, inflammation and depression risk in cancer survivors. Brain Behav Immun. 2013;30 Suppl(Suppl):S58-67. https://doi.org/10.1016/j. bbi.2012.05.002.

5. Die Trill M. Anxiety and sleep disorders in cancer patients. EJC Suppl. 2013;11(2):216-24. https://doi.org/10.1016/j.ejcsup.2013. 07.009 .

6. Mercadante S, Adile C, Ferrera P, Masedu F, Valenti M, Aielli F. Sleep disturbances in advanced cancer patients admitted to a supportive/palliative care unit. Support Care Cancer. 2017;25(4): 1301-6. https://doi.org/10.1007/s00520-016-3524-4.

7. Medysky ME, Temesi J, Culos-Reed SN, Millet GY. Exercise, sleep and cancer-related fatigue: are they related? Neurophysiol Clin. 2017;47(2):111-22. https://doi.org/10.1016/j.neucli.2017.03. 001.

8. Loh KP, Zittel J, Kadambi S, Pandya C, Xu H, Flannery M, et al. Elucidating the associations between sleep disturbance and depression, fatigue, and pain in older adults with cancer. J Geriatr Oncol. 2018;9(5):464-8. https://doi.org/10.1016/j.jgo.2018.02.006.

9. Gupta R, Das S, Gujar K, Mishra KK, Gaur N, Majid A. Clinical practice guidelines for sleep disorders. Indian J Psychiatry. 2017;59(Suppl 1):S116-S38. https://doi.org/10.4103/0019-5545. 196978.

10. Zhou ES, Partridge AH, Syrjala KL, Michaud AL, Recklitis CJ. Evaluation and treatment of insomnia in adult cancer survivorship programs. J Cancer Surviv. 2017;11(1):74-9. https://doi.org/10. 1007/s11764-016-0564-1.

11. Garland SN, Johnson JA, Savard J, Gehrman P, Perlis M, Carlson L, et al. Sleeping well with cancer: a systematic review of cognitive behavioral therapy for insomnia in cancer patients. Neuropsychiatr Dis Treat. 2014;10:1113-24. https://doi.org/10.2147/NDT.S47790 eCollection 2014.

12. Johnson JA, Rash JA, Campbell TS, Savard J, Gehrman PR, Perlis $\mathrm{M}$, et al. A systematic review and meta-analysis of randomized controlled trials of cognitive behavior therapy for insomnia (CBTI) in cancer survivors. Sleep Med Rev. 2016;27:20-8. https://doi. org/10.1016/j.smrv.2015.07.001.

13. Bernard P, Savard J, Steindorf K, Sweegers MG, Courneya KS, Newton RU, et al. Effects and moderators of exercise on sleep in adults with cancer: individual patient data and aggregated metaanalyses. J Psychosom Res. 2019;124:109746. https://doi.org/10. 1016/j.jpsychores.2019.109746.

14. Mercier J, Ivers H, Savard J. A non-inferiority randomized controlled trial comparing a home-based aerobic exercise program to a self-administered cognitive-behavioral therapy for insomnia in cancer patients. Sleep. 2018;41(10):1-15.

15. Clay JH. Basic clinical massage therapy: integrating anatomy and treatment: 2nd Ed. Lippincott Williams \& Wilkins; 2008.

16. Najafi Ghezeljeh T, Mohades Ardebili F, Rafii F. The effects of massage and music on pain, anxiety and relaxation in burn patients: randomized controlled clinical trial. Burns. 2017;43(5):1034-43. https://doi.org/10.1016/j.burns.2017.01.011.

17. Majchrzycki M, Kocur P, Kotwicki T. Deep tissue massage and nonsteroidal anti-inflammatory drugs for low back pain: a prospective randomized trial. ScientificWorldJournal. 2014;2014:287597. https://oi.org/10.1155/2014/287597.

18. Hachul H, Oliveira DS, Bittencourt LRA, Andersen ML, Tufik S. The beneficial effects of massage therapy for insomnia in postmenopausal women. Sleep Sci. 2014;7(2):114-6. https://doi.org/10. 1016/j.slsci.2014.09.005.

19. Yuan SL, Matsutani LA, Marques AP. Effectiveness of different styles of massage therapy in fibromyalgia: a systematic review and meta-analysis. Man Ther. 2015;20(2):257-64. https://doi.org/10. 1016/j.math.2014.09.003.

20. Cassileth BR, Vickers AJ. Massage therapy for symptom control: outcome study at a major cancer center. J Pain Symptom Manag. 2004;28(3):244-9. https://doi.org/10.1016/j.jpainsymman.2003. 12.016.

21. Seyedi Chegeni P, Gholami M, Azargoon A, Hossein Pour AH, Birjandi M, Norollahi H. The effect of progressive muscle relaxation on the management of fatigue and quality of sleep in patients with chronic obstructive pulmonary disease: A randomized controlled clinical trial. Complement Ther Clin Pract. 2018;31:64-70. https://doi.org/10.1016/j.ctcp.2018.01.010.

22. Hilfiker R, Meichtry A, Eicher M, Nilsson Balfe L, Knols RH, Verra ML, et al. Exercise and other non-pharmaceutical interventions for cancer-related fatigue in patients during or after cancer treatment: a systematic review incorporating an indirectcomparisons meta-analysis. Br J Sports Med. 2018;52(10):651-8. https://doi.org/10.1136/bjsports-2016-096422.

23. Ali B, Al-Wabel NA, Shams S, Ahamad A, Khan SA, Anwar F. Essential oils used in aromatherapy: a systemic review. Asian Pac J Trop Biomed. 2015;5(8):601-11. https://doi.org/10.1016/j.apjtb. 2015.05.007.

24. Higgins JP, Altman DG, Gøtzsche PC, Jüni P, Moher D, Oxman $\mathrm{AD}$, et al. The Cochrane Collaboration's tool for assessing risk of bias in randomised trials. BMJ. 2011;343:d5928. https://doi.org/10. 1136/bmj.d5928.

25. Toth M, Marcantonio ER, Davis RB, Walton T, Kahn JR, Phillips RS. Massage therapy for patients with metastatic cancer: a pilot randomized controlled trial. J Altern Complement Med. 2013;19(7):650-6. https://doi.org/10.1089/acm.2012.0466.

26. Miladinia M, Baraz S, Shariati A, Malehi AS. Effects of slowstroke back massage on symptom cluster in adult patients with acute leukemia: supportive care in cancer nursing. Cancer Nurs. 2017;40(1):31-8. https://doi.org/10.1097/ncc.0000000000000353.

27. Jacobs S, Mowbray C, Cates LM, Baylor A, Gable C, Skora E, et al. Pilot study of massage to improve sleep and fatigue in hospitalized adolescents with cancer. Pediatr Blood Cancer. 2016;63(5):880-6. https://doi.org/10.1002/pbc.25902.

28. Jane SW, Chen SL, Wilkie DJ, Lin YC, Foreman SW, Beaton RD, et al. Effects of massage on pain, mood status, relaxation, and sleep in Taiwanese patients with metastatic bone pain: a randomized clinical trial. Pain. 2011;152(10):2432-42. https://doi.org/10.1016/j. pain.2011.06.021.

29. Ducloux D, Guisado H, Pautex S. Promoting sleep for hospitalized patients with advanced cancer with relaxation therapy: experience of a randomized study. Am J Hosp Palliat Med. 2013;30(6):53640. https://doi.org/10.1177/1049909112459367. 
30. Nooner AK, Dwyer K, DeShea L, Yeo TP. Using relaxation and guided imagery to address pain, fatigue, and sleep disturbances: a pilot study. Clin J Oncol Nurs. 2016;20(5):547-52. https://doi.org/ 10.1188/16.cjon.547-552.

31. Zupanec S, Jones H, McRae L, Papaconstantinou E, Weston J, Stremler R. A sleep hygiene and relaxation intervention for children with acute lymphoblastic leukemia: a pilot randomized controlled trial. Cancer Nurs. 2017;40(6):488-96. https://doi.org/10.1097/ncc. 0000000000000457.

32. McCulloch R, Hemsley J, Kelly P. Symptom management during chemotherapy. Paediatr Child Health. 2018;28(4):189-95. https:// doi.org/10.1016/j.paed.2018.02.003.

33. Kaplow R. Sleep deprivation and psychosocial impact in acutely ill cancer patients. Crit Care Nurs Clin North Am. 2005;17(3):225-37. https://doi.org/10.1016/j.ccell.2005.04.010.

34. Fitzgerald T, Vietri J. Residual effects of sleep medications are commonly reported and associated with impaired patient-reported outcomes among insomnia patients in the United States. Sleep Disord. 2015;2015:607148-9. https://doi.org/10.1155/2015/ 607148.
35. Melton L. Cognitive behavioral therapy for sleep in cancer patients: research, techniques, and individual considerations. J Adv Pract Oncol. 2018;9(7):732-40.

36. Wang X, Smith C, Ashley L, Hyland ME. Tailoring self-help mindfulness and relaxation techniques for stroke survivors: examining preferences, feasibility and acceptability. Front Psychol. 2019;10: 391. https://doi.org/10.3389/fpsyg.2019.00391.

37. Twohig MP, Hayes SC, Plumb JC, Pruitt LD, Collins AB, HazlettStevens $\mathrm{H}$, et al. A randomized clinical trial of acceptance and commitment therapy versus progressive relaxation training for obsessive-compulsive disorder. J Consult Clin Psychol. 2010;78(5):705-16. https://doi.org/10.1037/a0020508.

38. Douglas JA, Chai-Coetzer CL, McEvoy D, Naughton MT, Neill AM, Rochford P, et al. Guidelines for sleep studies in adults - a position statement of the Australasian Sleep Association. Sleep Med. 2017;36(Suppl 1):S2-S22. https://doi.org/10.1016/j.sleep. 2017.03.019.

Publisher's note Springer Nature remains neutral with regard to jurisdictional claims in published maps and institutional affiliations. 